PENELITIAN

\title{
PERBEDAAN ANTARA PARASETAMOL DAN KETOROLAK TERHADAP KADAR SUBSTANSI P SERUM TIKUS WISTAR SEBAGAI ANALGESIK
}

\section{DIFFERENCE BETWEEN PARACETAMOL AND KETOROLAC AGAINST P SERUM SUBSTANCE AS PREEMPTIVE ANALGESIA}

\author{
Agus Purwo Hidayat*, M Sofyan Harahap**, Yulia Wahyu Villyastuti** \\ *PPDS 1 Bagian Anestesi dan Terapi Intensif FK Undip/RSUP Dr. Kariadi Semarang \\ **Staf Pengajar Bagian Anestesi dan Terapi Intensif FK Undip/RSUP Dr. Kariadi Semarang \\ ${ }^{\square}$ Correspondence/ Korespondensi : dr_yat@gmail.com
}

\begin{abstract}
Background: Preemptive analgesic is an analgesic interventions initiated before stimulation noxious appear in the conjunction with peripheral block or with central nociceptive. The aim is to decrease post-acute pain in trauma tissue, to prevent pain modulation in the central nervous system and prevent the occurrence of chronic pain. An important element in the process of pain perception is substance $P$ in which the function of sensory substance $P$ are related to the transmission of pain information to the central nervous system. Paracetamol and ketorolac as an anti-inflammatory steroid with antipyretic and analgesic effects and it's role in inhibiting the enzyme cyclooxygenase. The aim of this present study is to determine differences in the levels of substance $P$ in Wistar rats in both of the drugs as a selection in preemptive analgesic.
\end{abstract}

Objective: Knowing the difference in effectiveness between paracetamol and ketorolac which assessed on the levels of Substance P on Wistar rats as a preemptive analgesic.

Methods: This study is conducted as a laboratory experimental with Pre and post Randomize control group design test. A number of 21 rats, divided into three groups that carried out as random group, each consisting of 7 rats for the control group called K, 7 rats for the Paracetamol treatment group called K(1), 7 rats for the Ketorolac treatment group called $K$ (2). After being adapt for 7 days, the rats of the treatment group and the control are being anaesthetized by using ketamine. One hour prior to anaesthetize, group $K$ (1) were given an intravenous injection of $18 \mathrm{mg}$ paracetamol and group $K(2)$ are injected with $0.54 \mathrm{mg}$ intravenous ketorolac. After anaesthetized, the fur around rats back are shaved and disinfected using betadine. Furthermore, 2-cm depth incision is made until subcutaneous. Incision cleaned and smeared with betadine solution, then the wound is closed with five stitches using a simple single thread side and the stitching are cleaned, smeared with betadine and cared. After Post-surgery were also given penicillin oil $15 \mathrm{mg}$. Blood samples for examination of a Substance P levels performed on the group $K, K$ (1) and $K$ (2) 1 hour prior to the administration of paracetamol and ketorolac, and the 4th hour after the 
incision in Wistar rats model.

Results: Treatment demonstrated with Wistar rats model, there are two rats that dropped out, so the number of samples to be analyzed as many as 30 samples. With the Mann-Whitney test, levels of substance $P$ in the paracetamol group compared with ketorolac group were founded significantly different ( $p=0.016 ; p<0.005)$, whereas levels of substance P group Paracetamol founded lower than ketorolac group.

Conclusion: Giving paracetamol as a preemptive analgesic can reduce levels of substance $P$ in Wistar rats model are more significant than with ketorolac.

Keywords : Preemptive Analgesic, P Substance, Paracetamol, Ketorolac

\section{ABSTRAK}

Latar Belakang : Analgesik preemptif merupakan intervensi analgesik yang dimulai sebelum stimulasi noksius muncul dalam hubungannya dengan blok perifer maupun nosisepsi sentral. Tujuanannya untuk menurunkan nyeri akut pasca trauma jaringan, mencegah modulasi nyeri pada SSP dan mencegah terjadinya nyeri kronis. Elemen penting dalam proses persepsi nyeri adalah substansi $\mathrm{P}$ dimana Fungsi sensoris substansi P diperkirakan berkaitan dengan transmisi informasi nyeri ke sistem saraf pusat. Parasetamol dan ketorolak sebagai obat anti-inflamasi non steroid dengan efek antipiretik dan analgetik. Berperan dalam menghambat enzim siklooksigenase. Hal ini diharapkan dapat mengetahui perbedaan kadar substansi P tikus wistar pada keduanya sebagai pilihan analgesik preemptif.

Tujuan : Mengetahui perbedaan efektivitas antara Parasetamol dan Ketorolak yang dinilai dari kadar Substansi P pada tikus Wistar sebagai analgesik preemptif.

Metode : Penelitian ini merupakan eksperimental laboratorik dengan disain Rondomize Pre and Post test control group design. Sejumlah 21 ekor tikus, dibagi menjadi tiga kelompok yang dilakukan secara acak masing-masing terdiri dari 7 ekor tikus untuk kelompok kontrol (K), 7 ekor tikus untuk kelompok perlakuan parasetamol atau K(1), 7 ekor tikus untuk kelompok perlakuan ketorolak atau $\mathrm{K}(2)$. Setelah adaptasi selama 7 hari, tikus-tikus dari kelompok perlakuan maupun kontrol dilakukan pembiusan dengan menggunakan ketamin. Satu jam sebelum pembiusan, kelompok K (1) diberi injeksi paracetamol $18 \mathrm{mg}$ intravena dan kelompok $\mathrm{K}(2)$ diberi injeksi ketorolak 0,54 mg intravena. Sesudah terbius, bulu di sekitar punggung dicukur bersih dan didesinfeksi menggunakan betadine. Selanjutnya dibuat irisan sepanjang $2 \mathrm{~cm}$ dan kedalaman sampai subkutan. Luka irisan dibersihkan dan dioles larutan betadine, kemudian luka ditutup dengan lima jahitan tunggal sederhana menggunakan benang side. Selanjutnya jahitan dibersihkan, diolesi betadin dan dirawat. Paska pembedahan juga diberikan penisilin oil $15 \mathrm{mg}$. Pengambilan sampel darah untuk pemeriksaa kadar Substansi P dilakukan pada kelompok $K, K(1)$ dan $K(2) 1$ jam sebelum pemberian parasetamol dan ketorolak, dan pada jam ke-4 setelah dilakukan insisi pada tikus 
wistar.

Hasil : Dilakukan perlakuan terhadap tikus wistar, terdapat 2 ekor yang drop out, sehingga jumlah sampel yang dianalisa sebanyak 30 sampel. Pada Uji Mann-Whitney

\section{PENDAHULUAN}

Nyeri paska operasi adalah hasil yang tidak diinginkan yang paling umum untuk pasien yang menjalani prosedur bedah. Selain menyebabkan pasien menderita, nyeri pasca operasi dapat menunda pemulihan dan memperpanjang waktu tinggal di rumah sakit. Teknik Opioid dengan kombinasi menggunakan mekanisme analgesik yang berbeda dari tindakan diakui sebagai strategi komponen penting untuk manajemen nyeri pasca operasi. ${ }^{1}$

Nyeri yang sering tidak diobati, menyertai lebih dari 23 juta prosedur pembedahan yang dilakukan setiap tahun dan dapat bertahan lama setelah penyembuhan jaringan. Analgesik Preemtif, konsep klinis yang mulai berkembang, melibatkan pengenalan analgesik sebelum timbulnya rangsangan nyeri, dengan tujuan mencegah sensitisasi dari sistem saraf terhadap rangsangan berikutnya yang bisa memperkuat rasa sakit. ${ }^{2}$

Parasetamol merupakan obat antiinflamasi non steroid yang memiliki efek antipiretik dan analgetik. Efek analgetik parasetamol karena perannya dalam menghambat enzim siklooksigenase baik disentral maupun perifer. Mekanisme lain melalui jalur nitric oxide, dimana parasetamol menghambat hiperralgesia yang dimediasi substansi P. Cethan et al. menyebutkan pre-emptive intravena parasetamol dibandingkan dengan intra operasi parasetamol, menunjukkan hasil yang efektif dan dapat diandalkan sebagai analgesia pasca operasi setelah FESS.

Ketorolak adalah obat antiinflamasi nonsteroid injeksi dengan sifat analgesik. Smith et al. mengevaluasi efektivitas dosis tunggal ketorolak diberikan pasca operasi untuk pengobatan nyeri sedang sampai berat paska operasi dalam tinjauan kuantitatif dan hasilnya menunjukkan efek yang menguntungkan. Mayoritas penelitian yang terlibat dalam analisis yang dilakukan oleh Smith et al. meneliti formulasi oral ketorolak dan hanya 1 studi meneliti dosis sistemik yang lebih tinggi dari $30 \mathrm{mg}$. Review sistematis yang dilakukan oleh Smith et al. mengevaluasi efek dari ketorolak setelah pembentukan nyeri tapi anestesi paska operasi sering memberikan satu dosis ketorolak sistemik sebelum akhir prosedur bedah dalam upaya untuk mengurangi nyeri paska operasi; khasiat ketorolakserta efek ketergantungan dosis dalam keadaan yang belum ditetapkan.Beberapa penelitian menunjukkan bahwa ketorolak memiliki efek analgesik preemptif. $^{2}$ 
Potensi Parasetamol dan Ketorolak intravena sebagai analgesik preemptif dalam mengurangi nyeri paska operasi menarik untuk diteliti. Perlu diketahui perbedaan keduanya mengukur Substansi P sebagai mediator nyeri pada tikus Wistar.

\section{METODE}

Penelitian ini merupakan penelitian eksperimental laboratorik dengan disain Rondomize Pre and Post test control group design dengan tujuan mencari pengaruh pemberian parasetamol dan ketorolak intravena terhadap kadar substansi $\mathrm{P}$ dalam darah sebagai preemtif analgesi. Sampel penelitian 21 ekor tikus wistar jantan, sehat dan tidak tampak cacat secara anatomi Umur dua sampai dua setengah bulan Berat badan 250-300 gram Tidak terdapat abnormalitas anatomis yang tampak

Kelompok kontrol merupakan tikus wistar yang dilakukan insisi dan tidak diberi injeksi paracetamol maupun ketorolak sebelumnya. Kelompok perlakuan 1 merupakan tikus wistar yang dilakukan insisi sepanjang $2 \mathrm{~cm}$ dan diberi injeksi ketorolak intravena yang sebanding dengan dosis manusia $30 \mathrm{mg} 1$ jam sebelum insisi. Kelompok perlakuan 2 merupakan tikus wistar yang dilakukan insisi sepanjang $2 \mathrm{~cm}$ dan diberi injeksi paracetamol intravena yang sebanding dengan dosis manusia $1000 \mathrm{mg} 1$ jam sebelum insisi Dimana masing-masing kelompok dilakukan pegambilan darah dalam tabung EDTA dan dilakukan pengukuran subtasansi serum $P$

Dosis obat yang diberikan dikalikan konstanta uji terapi pada hewan coba tikus wistar yaitu 0,018. Jadi dosis yang diberikan yaitu :

Ketorolak $30 \mathrm{mg} \quad 30 \mathrm{mg} \times 0,018=$ $0,54 \mathrm{mg}$

Paracetamol $1000 \mathrm{mg} \quad 1000 \mathrm{mg}$ x $0,018=18 \mathrm{mg}$

\section{HASIL PENELITIAN}

Pemeriksaan kadar Substansi P dengan menggunakan reagen mouse elisa (ellabscience $^{T M}$ ) terhadap 42 sampel serum tikus Wistar. Masing-masing kelompok diwakili 7 sediaan uji. Pada saat dilakukan perlakuan terhadap tikus wistar, terdapat 2 ekor yang drop out, sehingga jumlah sampel yang dianalisa sebanyak 30 sampel, masing masing kelompok diwakili oleh 5 sampel tiap kelompok. Pemeriksaan sampel menggunakan spektrofotometri untuk pembacaan serum, intensitas warna area substansi $\mathrm{P}$ dapat diketahui sebagai penilaian kuantitatif.

Dari tabel 2 menunjukkan kelompok control(K), perlakuan parasetamol dan ketorolak baik pra maupun pasca perlakuan ,varian datanya tidak normal ( $\mathrm{p}>0,05)$, tetapi pada selisih didapatkan kelompok perlakuan ketorolak memiliki nilai $\mathrm{p}=0,003(\mathrm{p}<$ $0,005)$. Untuk selanjutnya dilakukan uji beda dengan One Way ANOVA, 
dilanjutkan dengan Paired $T$ Test untuk kelompok kontrol dan parasetamol, sedang untuk kelompok ketorolak dilakukan uji WilcoxonSelanjutnya dilakukan Uji beda berpasangan terhadap kelompok Perlakuan kontrol, Parasetamol dan ketorolak dengan One Way Anova, dilanjutkan Paired T Test. Jika tidak Normal/homogen dilanjutkan Kruskal wallis test dan one way anova.

Data dari tabel 3 menunjukan kadar substansi $\mathrm{P}$ antara kelompok kontrol (K), perlakuan parasetamol dan perlakuan ketorolak sebelum perlakuan (pre test) $\quad(p=0,385 ; p>0,05)$ tidak berbeda bermakna dan kadar substansi $\mathrm{P}$ antara kelompok kontrol,parasetamol dan ketorolak setelah perlakuan (post op) $(p=0,454 ; p>0,05)$ tidak berbeda bermakna.

Uji beda dilanjutkan dengan Paired $T$ test dan Wilcoxon, uji Paired $T$ test untuk membandingkan kelompok kontrol sebelum dan sesudah perlakuan dan untuk membandingkan kelompok parasetamol sebelum dan sesudah perlakuan, dan uji Wilcoxon untuk membandingkan kelompok ketorolak sebelum dan setelah perlakuan. Dari tabel di atas didapatkan bahwa perbedaan kadar substansi $\mathrm{P}$ pada kelompok parasetamol sebelum dan sesudah perlakuan berbeda bermakna $(\mathrm{p}$ $=0,014 ; \mathrm{p}<0,05)$, dan pada kelompok kontrol dan ketorolak kadar substansi $\mathrm{P}$ tidak berbeda bermakna antara sebelum perlakuan dengan setelah perlakuan.
0,024; $<0$,05), pada K2 kadar substansi $\mathrm{P}$ berbeda bermakna sebelum dan sesudah perlakuan $(\mathrm{p}=0,043 ; \mathrm{p}<0,05)$. Selanjutnya dilakukan uji beda selisih antara kelompok K, K1 dan K2

Dari data tabel 4 menunjukkan bahwa terdapat perbedaan bermakna antar kelompok K, K1 dan K2 ( $p=0,011$, $\mathrm{p}<0,05)$. Maka untuk melihat grup yang terdapat perbedaan bermakna dengan uji Mann Whitney

Dari data tabel 5 di atas didapatkan bahwa kadar substansi $\mathrm{P}$ pada kelompok Parasetamol dibandingkan dengan Kelompok Ketorolak berbeda bermakna $(p=0,016 ; p<0,005)$, kelompok Parasetamol dibandingkan dengan Kontrol juga berbeda bermakna $(\mathrm{p}=0,009 ; \mathrm{p}<0,005)$ dan kadar substansi $\mathrm{P}$ pada kelompok Kontrol dibandingkan dengan Ketorolak tidak berbeda bermakna $(p=0,465 ; p<0,05)$.

\section{PEMBAHASAN}

Pencegahan nyeri dengan analgesia preemptif menunjukkan angka keberhasilan yang cukup memuaskan hampir pada semua kelompok. Analgesik preemptif merupakan suatu tindakan tatalaksana nyeri yang dimulai sebelum tindakan pembedahan dengan tujuan mengurangi sensitisasi jalur nyeri perifer dan juga sentral akibat tindakan pembedahan. Tindakan "protektif" terhadap sistem nosiseptif pada tatalaksana analgesik preemptif lebih efektif jika dibandingkan dengan tatalaksana nyeri yang dilakukan pada 
saat pasca bedah. Secara teoritis, tindakan analgesia preemptif akan mengurangi nyeri pascabedah dan mencegah kejadian nyerikronik.

Pada penelitian ini dilakukan terhadap 21 ekor tikus wistar yang dilakukan insisi pada kulit punggung, kemudian untuk kontrol (K) tidak diberikan obat, pemberian parasetamol pada perlakuan 1 , dan ketorolak pada perlakuan 2 sebelum dilakukan insisi dan dilihat perbedaan kadar substansi $\mathrm{P}$ pada sebelum dan setelah perlakuan.

Untuk uji homogenitas kelompok dengan variabel yang dapat diukur, dimana didapat hasil statistik yang berbeda tidak bermakna dengan nilai $p=0,385$ (pre operasi) dan $p=0,0454$ (post operasi); $\mathrm{p}>0,05$ (tabel 7). Hal ini menunjukkan semua kelompok berasal dari populasi yang homogen, karena pada umumnya tikus berasal dari satu indukan dimana memiliki karakteristik yang mirip.

Dari analisis statistik, kadar substansi P didapatkan perbedaan bermakna antara kelompok kontrol (K) dengan kelompok parasetamol $(p=0,009 ; p<0,05), \quad$ dan kelompok parasetamol dan ketorolak pasca insisi $(p=0,0,016 ; p<0,05) \quad($ tabel 5). Pada penelitian ini bertujuan membuktikan perbandingan kadar substansi $\mathrm{P}$ pada parasetamol dan ketorolak yang merupakan penghambat COX yang tidak spesifik pada tikus wistar sebagai analgesia preemtif. Hasil menunjukkan bahwa dari kelompok pasca perlakuan yang diberi Parasetamol memiliki kadar substansi $\mathrm{P}$ lebih rendah dibandingkan dengan kelompok kontrol dan kelompok ketorolak, perbedaan kadar substansi $\mathrm{P}$ antara kelompok kontrol dengan kelompokparasetamol maupun ketorolak pasca insisi menunjukan perbedaan yang bermakna berdasarkan hasil uji selisih.

Parasetamol merupakan golongan sintetik non-opioid yang bekerja sebagai analgetik dan antipiretik sentral yang merupakan turunan dari paminofenol. Parasetamol bekerja secara sentral dengan cara menghambat sintesis prostaglandin dan juga enzin siklooksigenase, serta penghambatan transmisi sinyal melalui sistem serotogenik desenden pada sumsum tulang belakang.

Ketorolak merupakan analgetik poten yang termasuk golongan anti inflamasi nonsteroid yang mempunyai efek anti inflamasi sedang yang bekerja dengan cara menghambat enzim cyclooxygenase (COX) non selektif. Namun pada sistem hematologi, ketorolak dapat menghambat agregasi tombosit dan dapat memperpanjang waktu perdarahan karena ketorolak lebih banyak menghambat COX-1 dibanding COX-2. Pada sistem pencernaan ketorolak dapat menyebabkan iritasi lambung dan perdarahan gastrointestinal.

Pada penelitiannya Simin, dkk mengemukakan bahwa pemberian penecegahan parasetamol $1 \mathrm{gr}$ iv dapat 
menurangi intensitas nyeri di PACU dan sampai 4 jam setelah operasi dan konsumsi analgesik pada operasi sesar. Guldem Turan, dkk, dalam penelitiannya berpendapat bahwa paracetamol dan tramadol sebagai analgesia preemtif, efisien dalam menangani nyeri pasca operasi adenotonsilektomi pada anak-anak, meskipun antara paracetamol dengan tramadol tidak ada perbedaan yang signifikan.

Pada dasarnya, proses inflamasi merupakan respon fisiologis sebagai pertahanan tubuh yang bertujuan untuk membersihkan atau membuang penyebab cedera (seperti toksin atau mikroba) serta penyembuhan luka yang membutuhkan komponen seluler untuk membersihkan debris lokasi cedera serta meningkatkan perbaikan jaringan. Namun aktifitas sitokin proinflamasi yang berlebih dapat menyebabkan gangguan metabolisme berat, stabilitas hemodinamik dan gagal organ dan jika aktifitas anti inflamasi yang berlebih juga dapat menyebabkan kondisi imunocomprimised dan kerentanan terhadap infeksi.

Pada penelitian ini perbandingan parasetamol dan ketorolak sebagai analgetik preemtif didapatkan bahwa Parasetamol sebagai analgesik preemptif dalam menurunkan kadar substansi P lebih bermakna dibandingkan ketorolak sebagai analgesik preemptif. Namun kondisi ini kurang dapat menggambarkan keseluruhan proses inflamasi di jaringan yang memang sangat komplek dan dipengaruhi oleh berbagai faktor seperti neuroendokrin, metabolik dan imunologi. Sehingga perlu dilakukan penelitian lebih lanjut untuk melihat fenomena inflamasi di jaringan yang berhubungan dengan proses perbaikan jaringan yang luka berkaitan dengan faktor-faktor tersebut, terutama dalam kaitannya dengan analgesia preemtif.

\section{Kesimpulan}

Pemberian parasetamol sebagaianalgesia preemtif dapat menurunkan kadar substansi $\mathrm{P}$ pada tikus wistar lebih bermakna dibandingkan dengan ketorolak. 
Tabel 1. Hasil pengamatan rerata \pm SD (Median) kadar Substansi $\mathrm{P}$

\begin{tabular}{lcc}
\hline \multirow{2}{*}{ Variabel } & \multicolumn{2}{c}{ Kadar Substansi P } \\
\cline { 2 - 3 } & Pre Test & Post Test \\
\hline Kontrol & $506,1 \pm 82,18$ & $632,04 \pm 199,52$ \\
\hline Parasetamol & $585,37 \pm 74,58$ & $501,93 \pm 72,59$ \\
\hline Ketorolak & $538,53 \pm 103,61$ & $635,23 \pm 267,47$ \\
\hline
\end{tabular}

Tabel 2. Hasil Uji Normalitas dengan Saphiro Wilk

\begin{tabular}{llcl}
\hline & \multicolumn{3}{c}{ Shapiro-Wilk } \\
\cline { 2 - 4 } & \multicolumn{1}{c}{ Kelompok } & Statistik & Sig. \\
\hline Pre Ops & Kontrol & .980 & .936 \\
& Parasetamol & .914 & .495 \\
& Ketorolak & .962 & .820 \\
\hline Post Ops & Kontrol & .779 & .054 \\
& Parasetamol & .953 & .756 \\
& Ketorolak & .659 & .003 \\
\hline
\end{tabular}

Tabel 3. Hasil Uji Beda kadar substansi P (mean \pm SD) pada 3 kelompok

\begin{tabular}{cccc}
\hline Kelompok & PreOps & PostOps & P \\
\hline Kontrol & $506,1 \pm 82,18$ & $632,04 \pm 199,52$ & $0,178^{\S}$ \\
\hline Parasetamol & $585,37 \pm 74,58$ & $501,93 \pm 72,59$ & $0,014^{*}$ \\
& & $\S$ \\
\hline Ketorolak & $538,53 \pm 103,61$ & $635,23 \pm 267,47$ & $0,138^{\ddagger}$ \\
\hline $\mathrm{P}$ & $0,385^{£}$ & $0,454^{\ddagger}$ & \\
\hline Keterangan : ${ }^{\ddagger}$ One Way Anova; ${ }^{\ddagger}$ Kruskal Wallis test; ${ }^{\circledR}$ Paired t-test; ${ }^{¥}$ Wilcoxon test
\end{tabular}

Tabel 4. Hasil Perubahan kadar selisih substansi P pada 3 kelompok

\begin{tabular}{lcc}
\hline \multicolumn{1}{c}{ Kelompok } & Median (Min-Maks) & $\mathbf{p}^{\ddagger}$ \\
\hline Kontrol & $53,1(17,5-427,16)$ & \\
\hline Parasetamol & $-101,74(-130,22-(-19,89))$ & $0,011^{* \hbar}$ \\
\hline Ketorolak & $22,11(-20,14-415,93)$ & \\
\hline
\end{tabular}

Keterangan : ${ }^{\star}$ Kruskal Wallis test 
Tabel 5. Hasil uji beda Mann Whitney antar kelompok

\begin{tabular}{ccc}
\hline Kelompok & Parasetamol & Ketorolak \\
\hline Kontrol & $0,009^{*}$ & 0,465 \\
\hline Parasetamol & - & $0,016^{*}$ \\
\hline
\end{tabular}




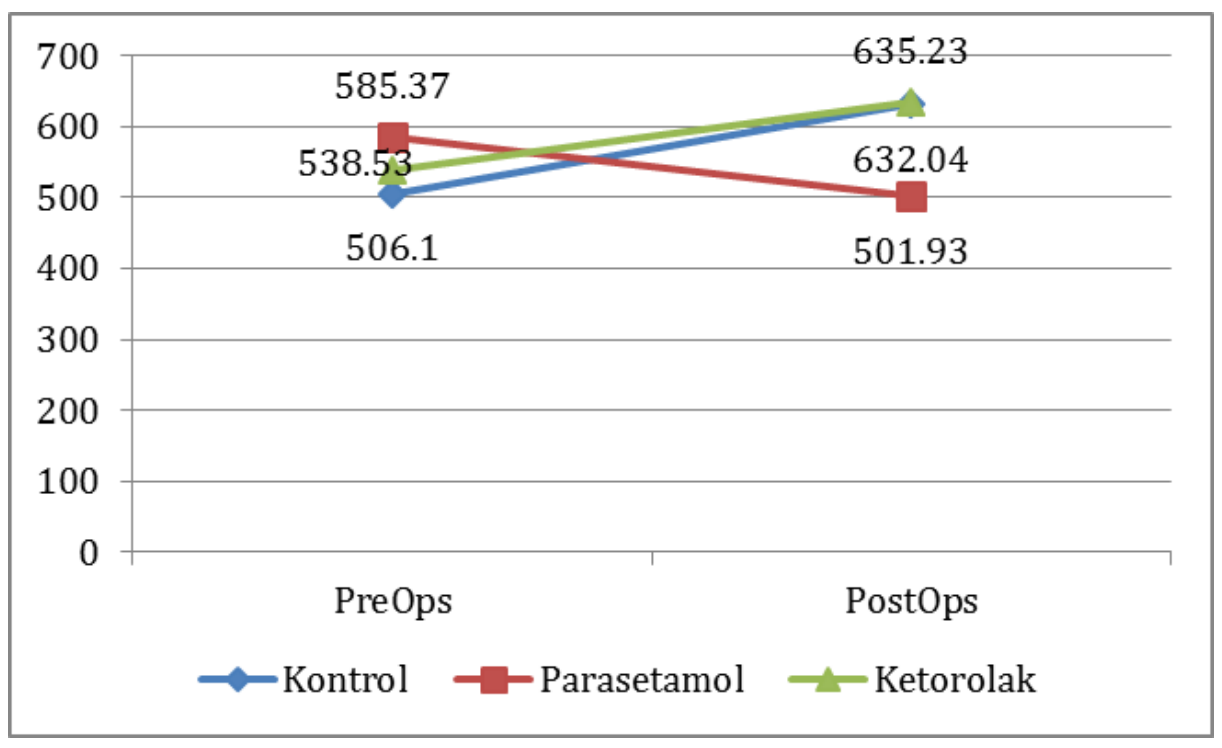

Gambar 1. Grafik uji Beda kadar substansi P pada 3 Kelompok
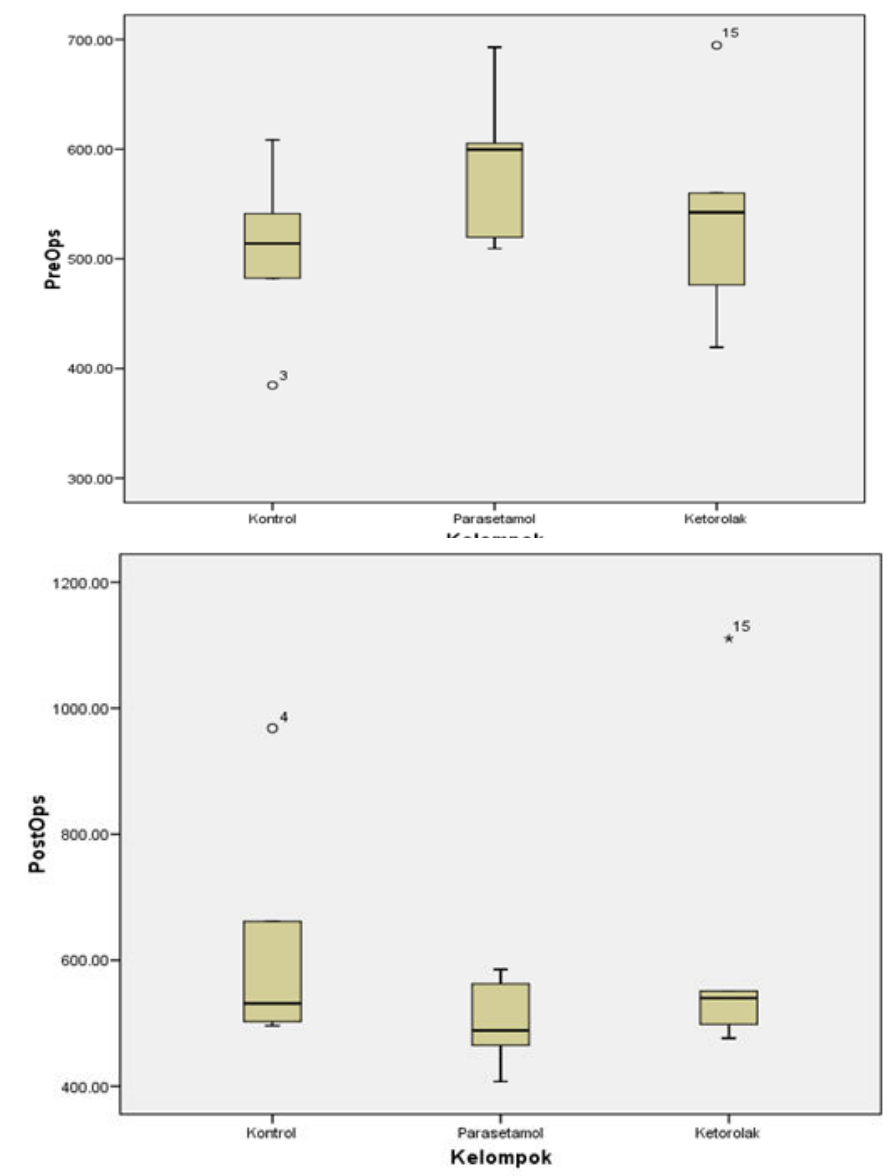

Gambar 2. Grafik scaterplot rerata substansi P pre dan post test 


\section{DAFTAR PUSTAKA}

1. Hurley,Robert. Acute postoperative Pain. Dalam: Miller RD. Miller's anesthesia. Edisi 7. Pennsylvania: Elsevier Churchill Livingstone; 2010. Hlm.2757-2781.

2. De Oliveria, Gildasio. Perioperative Single Dose Ketorolac to Prevent Postoperative Pain: A MetaAnalysis of Randomized Trials. Departement of anesthesiology, Northwestern University,Chicago; 2011

3. Gottschalk A. New concepts in acute pain theraoy: preemptive anelgesia. American family physician.2001;63 (10)

4. Kelly Dj,Ahmad M, Sorin J, Brull MD. Preemptive analgesia II: recent advances and current trends. Can J Anest 2001;48 (11): 1091-1101.

5. Sandkuhler J, Ruscheweyh R. Opioid and central sensitisation: I.Preemptive analgesia. European journal 2002;97(2): 306-14

6. Kissin i. Pain medicine preemptive anelgesia at the crossroad. Anesthesia analgesia 2005;100:7546

7. Substance P. Wikipedia [internet]. 2013 May 8 [cited 2013 June 16]. Available from: http:// en.wikipedia.org/wiki/Substance P

8. Turner RJ, Vink R. The Role Of Substance $\mathrm{P}$ In Ischaemic Brain Injury. Brain Sci 2013; 3: 123-142

9. Papp A, Valtonen P. Tissue substance $P$ levels in acute experimental burns. Burns 2006; 32: $842-5$

10. Duggan ST And Scott LJ. Intravenous Paracetamol (Acetaminophen).Drugs 2009;69:101-13

11. Wilsey B, Fishman S. Minor and short acting opioids. Essential of pain management and regional anesthesia $2^{\text {nd }}$ ed; 2005; 106-107.

12. OFIRMEV (acetaminophen) injection prescribing information. San Diego, CA: Cadence Pharmaceuticals, Inc.; November 2010. http://www.ofirmev.com/pdf/ OFIRMEV

PrescribingInformation.pdf. Diakses 20 Juni 2013

13. U.S. Food and Drug Administration. Acetaminophen overdose and liver injury-background and options for reducing injury; 22 Mei 2009. http:// www.fda.gov/ohrms/dockets/ac/09/ briefing/2009-4429b1-01-FDA.pdf. Diakses 20 Juni 2013

14. Skoglund LA, Skjelbred P, Fyllingen G. Analgesic efficacy of acetaminophen $\quad 1000 \mathrm{mg}$, acetaminophen $2000 \mathrm{mg}$, and the combination of acetaminophen 1000 $\mathrm{mg}$ and codeine phosphate $60 \mathrm{mg}$ versus placebo in acute postoperative pain. Pharmacotherapy. 1991;11:364-369

15. Pasero C, Stannard D. The Role of Intravenous Acetaminophen in Acute Pain Management. Pain Manag Nurs. 2012;13(2):107-124

16. Aronoff DM, Oates JA, Boutaud O. New Insights Into The Mechanism Of Action Of Acetaminophen: Its Clinical Pharmacologic Characteristics Reflect Its Inhibition Of The Two Prostaglandin H2 Synthases. Clin Pharmacol Ther. 2006 Jan;79(1):9-19

17. Smith HS. Potential Analgesic Mechanisms of Acetaminophen. Pain Physician 2009; 12:269-280

18. Malaise O, Bruyere O, Reginster JY. Intravenous Paracetamol: A Review Of Efficacy And Safety In Therapeutic Use. Future Neurology 2007; 22 (6): 673-88

19. Bertolini A, Ferrari A, Ottani A, Guerzoni S, Tacchi R, Leone S. Paracetamol: New Vistas Of An Old 
Drug. CNS Drug Reviews 2006; 12 (3-4): $250-75$

20. Mattia C, Coluzzi F. What Anesthesiologists Should Know About Paracetamol (Acetaminophen). Minerva Anestesiologica 2009; 75(11): 64453

21. Stouten E, Armbruster S, Houmes $\mathrm{R}$, et al. Comparison of ketorolac and morphine for postoperative pain after majorsurgery. Acta Anaesthesiol Scand ; 1992; 36:716721.

22. Brown C, Mazzulla J, Mok M, et al. Comparison of repeatdoses of intramuscular ketorolac tromethamine and morphinesulfate for analgesia after major surgery. Pharmacotherapy; 1990; 10:45S50S.

23. Bosek V, Smith D, Cox C. Ketorolac or fentanyl to supplementlocal anesthesia? J Clin Anesth ; 1992; 4:480-483.

24. Greer I. Effects of ketorolac tomethamine on hemostasisPharmacotherapy ; 1990; 10:71S-76S.

25. Burke A, Smyth E, Fitzgerald GA. Analgesic-antipyretic agents. In : Goodman \& Gilman's The Pharmacological Basis of Therapeutics 11th ed. The McGrawHill Companies ; 2006. 